\title{
Another Hole in the Wall? Evaluating the Legality of Egypt's 2017 Airstrikes Against Non-State Targets in Libya Under the Jus ad Bellum
}

\author{
Daley J. Birkett ${ }^{1,2}$ (D)
}

Accepted: 12 January 2022 / Published online: 3 February 2022

(c) The Author(s) 2022

\begin{abstract}
In May 2017, the Egyptian armed forces conducted airstrikes against non-State targets in the neighbouring State of Libya in response to a series of attacks perpetrated against groups of Coptic Christians on Egyptian territory, killings later claimed by the self-styled Islamic State. In justifying its use of armed force, resort to which is generally impermissible in international law, Egypt purports to rely upon two exceptions to this general rule, namely: (i) authorisation on the part of the United Nations Security Council; and (ii) self-defence, while also invoking the doctrine of military assistance on request (or intervention by invitation). This article tests the legality of Egypt's airstrikes — which have yet to be subjected to scholarly attention-in light of the three foregoing justifications. In so doing, the article evaluates the implications of this use of force for the jus ad bellum, particularly the law regulating resort to force by way of response to an armed attack for which not another State, but a nonState actor, is responsible.
\end{abstract}

Keywords Jus ad bellum $\cdot$ Use of force $\cdot$ Non-state actors $\cdot$ Self-defence $\cdot$ Military assistance on request · United Nations Security Council

Daley J. Birkett

daley.birkett@mq.edu.au

1 Macquarie Law School, Macquarie University, Sydney, Australia

2 War Reparations Centre, Amsterdam Center for International Law, University of Amsterdam, Amsterdam, The Netherlands 


\section{Introduction}

On 26 May 2017, a group of armed men attacked a convoy of vehicles carrying Coptic Christians in Egypt's Minya Governorate, killing at least 28 passengers and wounding many more. ${ }^{1}$ The self-styled Islamic State (IS) ${ }^{2}$ claimed responsibility for the attack the following day. ${ }^{3}$ Before the group was able to 'take credit' for the ambush, however, the Egyptian armed forces had already retaliated, launching a series of airstrikes against alleged militant training camps located on the territory of neighbouring Libya. ${ }^{4}$ In reporting its use of armed force to the United Nations Security Council (UNSC), as demanded by Article 51 of the UN Charter when States take measures in self-defence, ${ }^{5}$ Egypt appears to rely upon two exceptions to the general rule of public international law that the threat or use of armed force is impermissible, ${ }^{6}$ namely (i) UNSC authorisation of the resort of force and (ii) selfdefence, before turning to evaluate another legal basis on which Egypt seeks to rely to justify the airstrikes, i.e., military assistance on request. ${ }^{7}$ This article examines the legality of the justifications put forward by Egypt in support of its use of force on Libyan territory in response to what Egyptian officials considered to be an armed attack conducted by a non-State actor without any involvement on the part of the State of Libya.

The following paragraphs are divided into three sections. ${ }^{8}$ Section 2.1 briefly examines the events that led to the May 2017 airstrikes, from Muammar Gaddafi's removal from power in October 2011 following international intervention to the years-long battle for control over Libya between two competing regimes, each enjoying recognition at some stage, among other groups. Section 2.1 also demonstrates that it was in this context that militants were able to use parts of Libyan territory as bases from which to launch multiple, predominantly cross-border attacks against Coptic Christians. Additionally, Sect. 2.2 surveys the reaction of third States-with a focus on those most immediately impacted by the use of force under examination-and international organisations to both the terrorist attack and to Egypt's airstrikes.

The focus of Sect. 3 rests not on the context of the airstrikes but on their legality. Section 3.1 explores the legality of Egypt's use of force pursuant to UNSC

\footnotetext{
1 Walsh and Youssef (2016a).

2 Also known as the Islamic State in Iraq and the Levant (ISIL), the Islamic State in Iraq and Syria (ISIS), or by the Arabic acronym شع ش [Daesh].

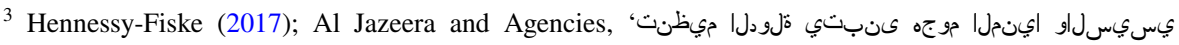
[ISIS Claims Minya Attack and El Sisi Threatens]', Al Jazeera (27 May 2017) https://www.aljaz eera.net/news/arabic/2017/5/27//ليبكت رم-دعوتيو -طابقألا-نئمطي-بيسيس.

4 Walsh and Youssef (2016a).

5 Art. 51 UN Charter (Measures taken by Members in the exercise of [the] right of self-defence shall be immediately reported to the Security Council). For analysis of State practice with respect to this requirement, see Green (2015).

6 Art. 2(4) UN Charter.

7 Also known as '(military) intervention by invitation'. See e.g. Doswald-Beck (1985), Bannelier and Christakis (2013), Visser (2019).

8 The structure is inspired by that adopted throughout Ruys et al. (2018).
} 
Resolution 2292, which '[u]rges Member States to combat by all means ... threats to international peace and security caused by terrorist acts', 9 among other measures the UNSC adopted under Chapter VII of the UN Charter to respond to the threat posed by militants in Libya. Section 3.2 turns to assess Egypt's claim that it acted in self-defence. In particular, this section questions whether the dictum of the majority of the International Court of Justice (ICJ) in its Advisory Opinion on the Legal Consequences of the Construction of a Wall in the Occupied Palestinian Territory (Wall Advisory Opinion) that this right can only be exercised 'in the case of armed attack by one State against another State' ${ }^{10}$ can be said to constitute an accurate reading of Article 51 the UN Charter. Taking the 2017 airstrikes as a case study, the article proposes that this use of force is another example of State practice and opinio juris in support of a 'wider' right to self-defence. Put otherwise, this article contends that Egypt's use of force against militants in Libya lends additional weight to the belief expressed by Judge Simma in his Separate Opinion in Armed Activities on the Territory of the Congo (Armed Activities') that 'large-scale attacks by non-State actors can qualify as "armed attacks" within the meaning of Article 51', ${ }^{11}$ an opinion shared by some of his judicial colleagues ${ }^{12}$ and members of the academic community. ${ }^{13}$ Section 3.3 analyses the lawfulness of Egypt's use of force 'in coordination with the national army of Libya', focusing especially on the question of how the doctrine of military assistance on request operates when competing regimes claim control over the requesting State's territory and institutions.

Section 4 concludes the article, submitting that, although some of the legal justifications for using force (ostensibly) proffered by Egypt have more merit than others, none renders its May 2017 use of force against non-State targets in Libya permissible under the jus ad bellum schema.

\footnotetext{
9 UNSC Res. 2292, UN Doc. S/RES/2292, 14 June 2016, para. 2.

${ }^{10}$ Legal Consequences of the Construction of a Wall in the Occupied Palestinian Territory (Advisory Opinion) [2004] ICJ Reports 136 (Wall Advisory Opinion), p. 194.

${ }^{11}$ Armed Activities on the Territory of the Congo (Democratic Republic of the Congo v. Uganda) (Judgment) [2005] ICJ Reports 168 (Armed Activities), p. 337 (separate opinion of Judge Simma).

12 Ibid., pp. 314-315 (separate opinion of Judge Kooijmans). For similar views, see Wall Advisory Opinion, above n. 10, p. 215 (separate opinion of Judge Higgins), p. 230 (separate opinion of Judge Kooijmans), p. 242 (Declaration of Judge Buergenthal).

13 See e.g. van Steenberghe (2016), p. 46, observing that ' $[\mathrm{t}]$ he majority of scholars, including those who could be called "restrictivists", now recognize the right of states to respond in self-defence to any armed attack, whatever the state or non-state origin of such attack'. However, the argument that this is now the majority view remains contested. See Corten 2016b. Inter alia, the plea states that an armed attack 'may occur either where acts of war perpetrated by a terrorist group can be attributed to the State, or by virtue of a substantial involvement of that State in the actions of such groups.' As of 14 September 2016, 243 professors had signed the plea. See Contre une invocation abusive de la légitime défense pour faire face au défi du terrorisme-A plea against the abusive invocation of self-defence as a response to terrorism (6 October 2016) http://cdi.ulb.ac.be/contre-invocation-abusive-de-legitime-defense-faire-face-defi-terro risme/.
} 


\section{The Context of the 2017 Airstrikes}

The 26 May 2017 ambush in Minya was not the first orchestrated by militants against Coptic Christians in Egypt. Nor was this the first such attack to which Egypt responded with armed force. Indeed, the incident that forms the subject of the present article is part of a series of (primarily cross-border) attacks launched by terrorist groups from bases located in eastern Libya. This section briefly examines the events that allowed such militant-friendly conditions to take hold in Libya before considering the attacks that preceded and followed the May 2017 incident as well as Egypt's respective responses thereto. The section then turns to the reaction of third States and international organisations to the attack and the Egyptian airstrikes.

\subsection{Post-Gaddafi Libya}

Revolutionaries commanded by Muammar Gaddafi deposed Libya's monarchy in a largely bloodless coup d'état on 1 September $1969,{ }^{14}$ heralding the beginning of what was to be a 42-year reign. It was not until 20 October 2011 that anti-Gaddafi forces succeeded, after a months-long civil war that drew the intervention of the UNSC and NATO,${ }^{15}$ in ousting the regime by capturing and executing its leader. ${ }^{16}$ The Gaddafi administration was replaced with rule by the Transitional National Council (TNC) until the parliamentary elections of 7 July 2012, when the General National Congress (GNC) was established. ${ }^{17}$ But this election was reported to have taken place amidst lawlessness, violence, and inter-tribal warfare, with cities 'under the control of fractious militias', ${ }^{18}$ a continuation of the prevailing situation during the preceding nine months of TNC rule, especially in eastern Libya. ${ }^{19}$ This 'relentless violence, ${ }^{20}$ also formed the backdrop to the June 2014 election of the House of Representatives (HoR), arranged by virtue of an amendment to Libya's interim constitution, ${ }^{21}$ to replace the GNC at the end of its term. ${ }^{22}$ Indeed, it was even reported

\footnotetext{
$\overline{{ }^{14} \text { Vandewalle (2012), pp. 77-78. }}$

15 Ibid., p. 204, citing UNSC Res. 1973, UN Doc. S/RES 1973, 17 March 2011, which established a 'No Fly Zone' in Libyan airspace. See also UNSC Res. 1970, UN Doc. S/RES/1970, 26 February 2011, which, among other measures, referred the situation in Libya to the International Criminal Court and requested UN Member States to implement targeted sanctions against Muammar Gaddafi and other individuals associated with his regime.

16 Ibid., p. 208.

${ }^{17}$ Kirkpatrick (2012).

18 Ibid.

19 Ibid.

${ }^{20}$ Fahim and Zway (2014).

${ }^{21}$ For discussion, see Maghur (2014).

22 Ibid. The author adds: 'However, Article 30 of the Constitutional Declaration did not clearly mandate the length of the GNC's term in office. Consequently, the second transfer of power was turbulent and triggered war rather than peace and stability.'.
} 
that voting was unable to take place in the eastern city of Derna, where IS militants had established a presence, 'over fears that militants would try to intimidate voters'. ${ }^{23}$ Meanwhile, in Benghazi, another city on Libya's east coast, 'renegade general' ${ }^{24}$ Khalifa Haftar was waging 'a campaign to purge the country of Islamist lawmakers and militias, sending troops and ... warplanes to move against militia bases'. 25

Despite enjoying international support, ${ }^{26}$ the HoR, which had relocated to the eastern city of Tobruk (working in hotels and even a rented car ferry) in August $2014,{ }^{27}$ saw its legal basis - the foregoing amendment to Libya's 2011 Constitutional Declaration-declared void by the (Tripoli-based) Supreme Court in November of the same year. ${ }^{28}$ The GNC 'resume[d] its legislative activities in Tripoli' following this decision, ${ }^{29}$ which, as the International Crisis Group observes, gave 'further ammunition to GNC members who rejected the HoR' ${ }^{30}$ At the same time, the HoR disregarded this ruling and continued to enjoy international recognition. ${ }^{31}$ Until December 2015, control over Libya was accordingly divided between the Tobrukbased HoR - which had notably appointed General Haftar as the commander of its armed forces in March 2015 32 - and the Tripoli-based GNC, as well as other Islamist and tribal factions. ${ }^{33}$ A UN-sponsored political agreement reached in Skhirat, Morocco, with support from members of the two rival parliaments, resulted in the establishment of a national unity government, the Government of National Accord (GNA), in December 2015. ${ }^{34}$ Significantly for the purpose of the legal evaluation that follows in Sect. 3, later that same month, the UNSC unanimously endorsed the GNA 'as the sole legitimate government of Libya'. ${ }^{35}$ Nevertheless, control over Libyan territory and State institutions remains divided between the GNA and the HoR, which has (generally) ${ }^{36}$ supported and received the backing of the Haftar-led Libyan National Army (LNA) — not to be confused with forces loyal to the GNA $^{37}$ —among

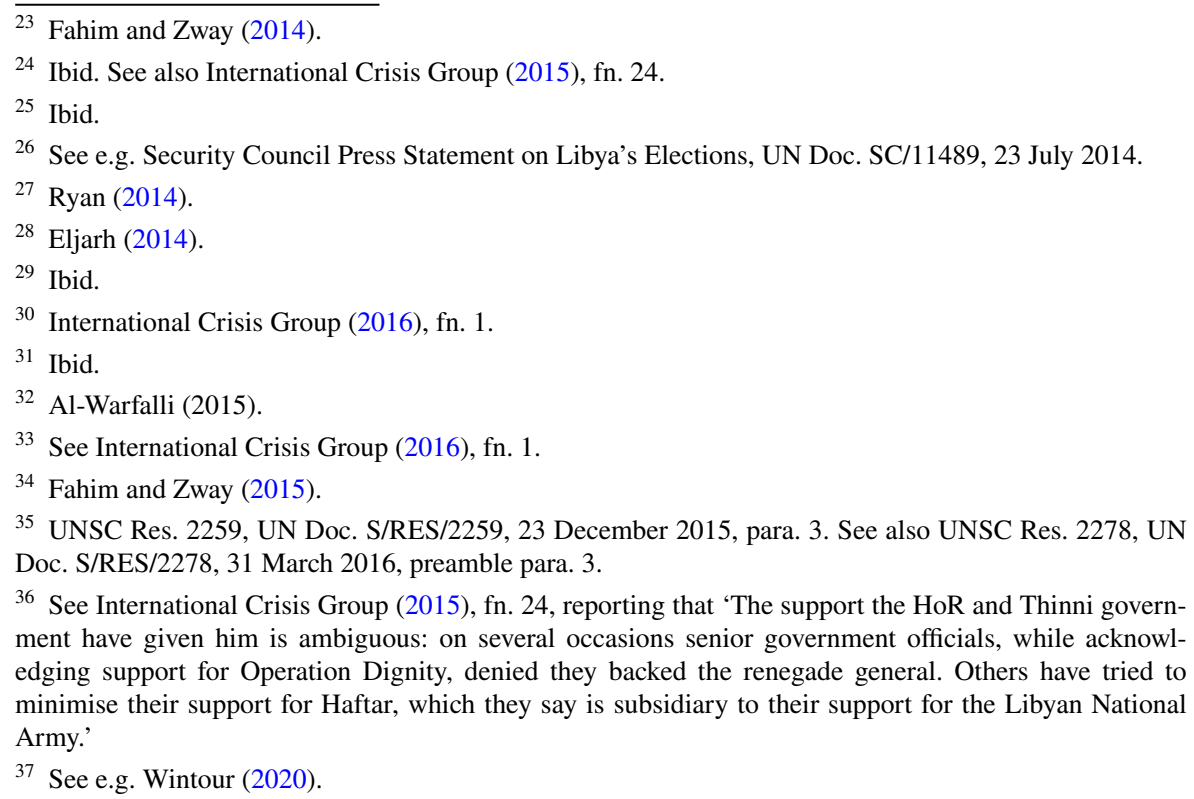


other groups. What is more, though the UNSC explicitly endorsed the GNA as the de jure government of Libya in December 2015, several States, including Egypt, have allegedly since provided the HoR and the LNA with material and financial support, ${ }^{38}$ while others similarly assist the GNA. ${ }^{39}$

Jon Lee Anderson summarises the situation, in an article published in The New Yorker magazine in February 2015, as follows:

There is no overstating the chaos of post-[Gaddafi] Libya. Two competing governments claim legitimacy. Armed militias roam the streets. The electricity is frequently out of service, and most business is at a standstill; revenues from oil, the country's greatest asset, have dwindled by more than ninety per cent. Some three thousand people have been killed by fighting in the past year, and nearly a third of the country's population has fled across the border to Tunisia. What has followed the downfall of a tyrant-a downfall encouraged by NATO air strikes-is the tyranny of a dangerous and pervasive instability. ${ }^{40}$

It was in the context of such 'pervasive instability' that militant groups were able to establish bases on Libyan territory, bases from which they conducted a wave of terrorist attacks against Coptic Christians in both Libya and Egypt, including the 26 May 2017 ambush. It is to these attacks that the present discussion now turns.

The first attack in the series was made publicly known on 15 February 2015 when IS released a video purportedly showing the beheading of 21 Egyptian Coptic Christians in the Libyan city of Sirte. ${ }^{41}$ Acting with the explicit consent of the then-internationally recognised Libyan Government (the HoR), ${ }^{42}$ Egypt retaliated by launching airstrikes against IS in Libya 'in coordination with the Libyan air force'. ${ }^{43}$ A second attack occurred on 11 December 2016 in the Egyptian capital, Cairo, when an IS-supporting suicide bomber detonated an explosive device inside St Mark's Coptic Orthodox Cathedral, killing 25

\footnotetext{
${ }^{38}$ See e.g. Wintour (2019) (alleging support for 'the parallel administration based in Libya's east' in the form of 'funding and arms'); Badi (2020) (discussing military and diplomatic support for the LNA on the part of the United Arab Emirates and France).

${ }^{39}$ See e.g. International Crisis Group (2020); QNA (2020). A copy of the latter is available-in Arabic_at @libyaalahrartv (Libya Al Ahrar TV) (Twitter, 26 October 2020, 12:21 pm GMT) https://twitt er.com/libyaalahrartv/status/1320702103925497858, while a copy of the 2019 Memorandum of Understanding between Turkey and the GNA is available—in Arabic and English—at Bozkurt (2019).

${ }^{40}$ Anderson (2015).

${ }^{41}$ Kirkpatrick and Callimachi (2015).

${ }^{42}$ See Bannelier-Christakis (2016), p. 756, citing UN SCOR, 70th sess, 7387th mtg, UN Doc. S/ PV.7387, 18 February 2015, p. 5.

${ }^{43}$ Ibid.
} 
people. ${ }^{44}$ More IS-coordinated attacks against Coptic Christians in Egypt took place on 9 April 2017-Palm Sunday-when militants affiliated to IS bombed St George's Church and St Mark's Cathedral in the cities of Tanta and Alexandria, respectively, with the twin attack causing the deaths of 44 people. $^{45}$ It was subsequent to these bombings that the ambush against the convoy of vehicles took place in Minya. The May 2017 attack was, in turn, followed by further killings of Coptic Christians in Egypt for which IS claimed responsibility. These include the murder by IS gunmen of nine people at the Mar Mina Church in Helwan on 29 December $2017^{46}$ and a second attack in the Minya Governorate on 2 November 2018. ${ }^{47}$ Like the May 2017 attack, the latter was directed against buses carrying pilgrims to the Monastery of St Samuel the Confessor. ${ }^{48}$ At least seven Coptic Christians were killed in the 2018 ambush, with sixteen more wounded. ${ }^{49}$

Discussing the airstrikes that Egypt's armed forces carried out in 2015 in response to the first attack in this series of mass killings, Karine BannelierChristakis observes that ' $[\mathrm{t}]$ he declarations of both states made it clear that the legal basis of the airstrikes was valid consent by Libya combined with the fact that the objective was the common fight against terrorism. ${ }^{50}$

But this conclusion, with which the present author concurs, cannot simply be replicated with respect to the use of force under examination in the following paragraphs. Rather, the legality of the airstrikes that form the subject of this article merit a closer inspection, not least because of the establishment-and ensuing recognition-of the GNA in the period between the 2015 and 2017 uses of force. The question of whether Libya's purported consent to Egypt's use of armed force on its territory in May 2017 was similarly valid to its February 2015 counterpart will accordingly be addressed, together with two additional justifications that Egypt arguably puts forward when reporting its airstrikes to the UNSC, in Sect. 3. Before turning to consider this issue, however, the article will first scrutinise the reaction of third States and international organisations to the 2017 airstrikes, which, it is hoped, might shed further light on the legality of Egypt's conduct.

\footnotetext{
44 Walsh and Youssef (2016b)

45 Samaan and Walsh (2017).

46 Youssef (2017).

47 Walsh and Ezz (2018).

48 Ibid.

49 Ibid.

${ }^{50}$ Bannelier-Christakis (2016), p. 756.
} 


\subsection{International Reaction}

Multiple States condemned the 26 May 2017 terrorist attack in Minya. These include, inter alia ${ }^{51}$ Algeria,${ }^{52}$ Bahrain,${ }^{53}$ Canada,${ }^{54}$ China,${ }^{55}$ France,,${ }^{56}$ Germany, ${ }^{57}$ Greece ${ }^{58}$ Israel,${ }^{59}$ Japan, ${ }^{60}$ Jordan, ${ }^{61}$ Pakistan, ${ }^{62}$ Singapore, ${ }^{63}$ Switzerland, ${ }^{64}$ Syria,${ }^{65}$

\begin{tabular}{l}
\hline Egypt's official State Information Service reports condemnation (and, in certain cases and to varying \\
degrees, support for Egypt in its fight against terrorism) on the part of Saudi Arabia, the United Arab \\
Emirates, Bahrain, Palestine, Jordan, Iraq, Russia, the United Kingdom, Algeria, Kuwait, the Arab Par- \\
liament, 'the Libyan interim government', the Organization of Islamic Cooperation, France, and Oman. \\
'Arab, int'l condemnation of Minya terrorist attacks', State Information Service (27 May 2017) https:// \\
www.sis.gov.eg/Story/113185. \\
52 'L'Algérie condamne "avec vigueur" l'attentat terroriste ayant ciblé un bus dans la province de Minya' \\
(26 May 2017), http://www.mae.gov.dz/news_article/4849.aspx. \\
53 Ministry of Foreign Affairs of Kingdom of Bahrain condemns terrorist attack in Minya in Arab \\
Republic of Egypt' ( 26 May 2017), https://www.mofa.gov.bh/Default.aspx?tabid=7824\&language=en- \\
US\&ItemId=7442. \\
54 Statement by the Prime Minister of Canada on the terrorist attack on Coptic Christians in Egypt' (26
\end{tabular} May 2017) https://pm.gc.ca/en/news/statements/2017/05/26/statement-prime-minister-canada-terroristattack-coptic-christians-egypt.

55 'Foreign Ministry Spokesperson Lu Kang's Remarks on Terrorist Attack in Egypt' (27 May 2017) http://eg.china-embassy.org/eng/fyrth/t1465871.htm.

${ }^{56}$ Egypt-Terrorist attack in Minya province-Statement by M. Jean-Yves Le Drian, Minister for Europe and Foreign Affairs (26 May 2017)' (26 May 2017) https://www.diplomatie.gouv.fr/en/countryfiles/egypt/news/article/egypt-terrorist-attack-in-minya-province-statement-by-m-jean-yves-le-drian.

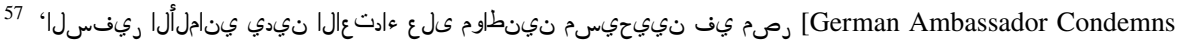
the Attack on Christian Citizens in Egypt]' (27 May 2017) https://kairo.diplo.de/eg-ar/aktuelles/-/19887 40.

${ }^{58}$ Foreign Ministry announcement on the deadly terrorist attack in Egypt' (26 May 2017) https://www. $\mathrm{mfa} . \mathrm{gr} / \mathrm{en} / \mathrm{current}$-affairs/statements-speeches/foreign-ministry-announcement-on-the-deadly-terroristattack-in-egypt.html.

59 Israel Strongly Condemns the Terrorist Attack in Egypt' (26 May 2017) https://www.gov.il/en/Depar tments/news/spokeegypt270517.

60 'Terror attacks in Minya, Egypt (Statement by Foreign Press Secretary Norio Maruyama)' (29 May 2017) https://www.mofa.go.jp/press/release/press4e_001604.html.

61 'King condemns terrorist attack on Coptic bus in Minya' (26 May 2017) https://kingabdullah.jo/en/ news/king-condemns-terrorist-attack-coptic-bus-minya.

62 'Pakistan Condemns Terrorist Attack in Egypt' (28 May 2017)<http://mofa.gov.pk/pakistan-conde mns-terrorist-attack-in-egypt-2/.

63 'MFA Press Statement: Condolence letters from Singapore leaders on the attack on Coptic Christians in Minya, Egypt on 26 May 2017' (27 May 2017) https://www.mfa.gov.sg/Newsroom/Press-StatementsTranscripts-and-Photos/2017/05/MFA-Press-Statement-Condolence-letters-from-Singapore-leaders-onthe-attack-on-Coptic-Christians-in.

${ }^{64}$ Attack in Egypt-FDFA position statement' (26 May 2017) https://www.admin.ch/gov/en/start/ documentation/media-releases.msg-id-66862.html.

[Syria Condemns in the Strongest Terms the Terrorist Attack in Minya: Evidence of the Exacerbation of the Pheاترارابعلادشأبنيدتثيروس/2017), http://www.mofa.gov.sy/ar/pages877 مقافتىل عليلداينملايفيباهد إلاموجه 
Turkey, ${ }^{66}$ the United Arab Emirates, ${ }^{67}$ the United Kingdom, ${ }^{68}$ and the United States of America. ${ }^{69}$ The Organisation of Islamic Cooperation, ${ }^{70}$ the European Union, ${ }^{71}$ and all UNSC Member States ${ }^{72}$ also denounced the attack claimed by IS, though none of the foregoing official media releases offered explicit support for Egypt's resort to force by way of response thereto. Nor, however, did these States denounce the Egyptian airstrikes. This is the case even though several of the statements were issued after Egypt's use of force, which, as will be examined in greater detail in Sect. 3, very swiftly followed the attack. ${ }^{73}$ It was only the Secretary-General of the League of Arab States, Ahmed Aboul Gheit, who went on the record in a very brief interview as expressing the view that the Egyptian airstrikes were 'very much' justified. $^{74}$

However, what is of arguably greater import is that Libya's internationally recognised Government - the GNA - that is to say, the representatives of the State most acutely affected by the use of force, did condemn the airstrikes. ${ }^{75}$ The Libyan Presidential Council reportedly rejected what it viewed as a violation of Libya's sovereignty, condemning in a statement the bombing by Egypt of sites on Libyan territory without the involvement of Libya's legitimate authorities recognised on the Arab,

\footnotetext{
66 No. 159, 26 May 2017, Press Release Regarding the Terrorist Attack in Egypt' (26 May 2017) http:// www.mfa.gov.tr/no_-159_-26-may-2017_-press-release-regarding-the-terrorist-attack-in-egypt.en.mfa.

67 UAE condemns terrorist attack on bus in Egypt' (26 May 2017), https://www.mofaic.gov.ae/en/media hub/news/years/2017/5/26/26-05-2017-uae-egypt.

68 'Minister for North Africa statement on terrorist attack in Egypt' (26 May 2017), https://www.gov.uk/ government/news/minister-for-north-africa-statement-on-terrorist-attack-in-egypt.

69 'Statement by President Donald J. Trump on the Attack in Egypt' (26 May 2017), https://eg.usemb assy.gov/statement-president-donald-j-trump-attack-egypt/.

70 'OIC Condemns Terrorist Attack in Minya Governorate, South of Egypt' (26 May 2017), https:// www.oic-oci.org/topic/?t_id=13635\&ref=5934\&lan=en.

71 'Statement by the Spokesperson on the attack in Egypt' (26 May 2017), https://eeas.europa.eu/deleg ations/iceland/26980/attack-egypt_en.

72 Security Council Press Statement on Terrorist Attack in Minya, Egypt, UN Doc. SC/12845 (26 May 2017); UN SCOR, $72^{\text {nd }}$ sess, $7952^{\text {nd }} \mathrm{mtg}$, UN Doc. S/PV.7952 (26 May 2017). The Members States of the UNSC at the time of the attack and its subsequent condemnation comprised Uruguay (President), Bolivia, China, Egypt, Ethiopia, France, Italy, Japan, Kazakhstan, Russia, Senegal, Sweden, Ukraine, the United Kingdom, and the United States of America. The UN Secretary-General separately condemned the terrorist attack. See Secretary-General Condemns 'Despicable' Terrorist Attack in Egypt, UN Doc. SG/SM/18539, 26 May 2017.
}

73 See below n. 172 and accompanying text.

74 RT, 'Egypt's airstrikes in Libya 'very much justified'-Arab League Secretary-General Gheit' (YouTube, 30 May 2017) 0:00:30-0:00:31 https://www.youtube.com/watch?v=29I-rvNd31s\&list=ULFmt ل212wcy7E. The Secretary-General was, however, less explicit in an earlier media release. See لودلاة | posts/1294858707230421.

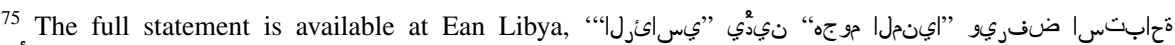

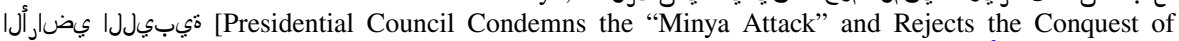

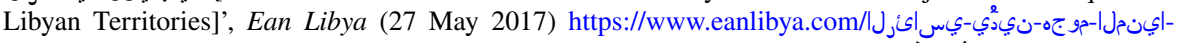

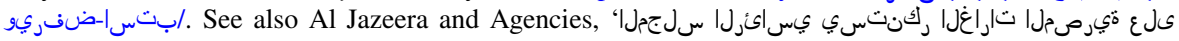
(Presidential Council Denounces Egyptian Raids on Libya]', Al Jazeera (27 May 2017), https://

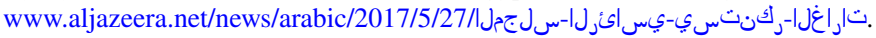


African, and international planes. ${ }^{76}$ The statement by the Presidential Council is also reported to have emphasised the desire of the GNA to coordinate future counterterrorism operations, at home and overseas, under the auspices of international and Islamic alliances, with full respect for national sovereignty. ${ }^{77}$ Despite this statement, the representatives of the GNA did not condemn Egypt's airstrikes at the international level. This is despite having had opportunities to do so in ensuing meetings of the UNSC addressing the situation in Libya. ${ }^{78}$ It could therefore be reasonably concluded that States sympathised with Egypt's situation as a victim of terrorist atrocities without necessarily endorsing its airstrikes. Other scholars might go further and argue that such a response constitutes acquiescence. For example, multiple scholars have interpreted 'silence' on the part of States-particularly those most directly affected-to mean their implicit authorisation of measures involving the use of force, ${ }^{79}$ while others take a more cautious approach. ${ }^{80}$

The present author finds it difficult to disagree with Luca Ferro, who, after analysing recent State practice, including in Libya, ${ }^{81}$ reaches the conclusion that third States' silence in response to another State's military action, not least when the use of force is accompanied by an arguably ambiguous legal justification, cannot be construed as acquiescence thereto. ${ }^{82}$ As the following paragraphs will demonstrate, Egypt alludes to-if not explicitly invokes-three possible grounds underpinning its 2017 airstrikes in Libya, none of which are uncontroversial in their application. Erring on the side of caution, the muted reaction of third States to Egypt's use of force-if not the attack in Minya-offers scant support for any claim that the airstrikes were lawful under the jus ad bellum.

\section{The Legality of Egypt's Use of Force}

The starting point of any inquiry into whether a use of force, including in response to an armed attack perpetrated by a non-State actor operating from the territory of another State, is permissible under international law is the UN Charter. It is in Article 2(4) of the treaty that established the UN that one finds the general prohibition on the (threat or) use of force:

\footnotetext{
76 Ibid.

77 Ibid.

78 The representative of Libya was invited to participate in meetings of the UNSC on 7 June 2017 and 12 June 2017. In neither of those meetings was the issue of Egypt's use of force raised. See UN SCOR, $72^{\text {nd }}$ sess, 7961 ${ }^{\text {st }} \mathrm{mtg}$, UN Doc. S/PV.7961, 7 June 2017; UN SCOR, 72nd sess, 7964th mtg, UN Doc. S/PV.7964, 12 June 2017.

79 See e.g. Aragón Cardiel et al. (2018), pp. 142-143; Scharf (2016), pp. 50-51.

80 See e.g. Corten (2010), p. 21; Henry (2017), Starski (2017).

81 Ferro (2021), examining armed interventions by Turkey in Libya and by Saudi Arabia and the United Arab Emirates in Yemen.

82 Ibid., p. 10. Ferro argues: 'It ... appears impossible to infer acquiescence from silence in response to controversial State action followed by an ambiguous legal justification or one that is entirely absent.'
} 
All Members shall refrain in their international relations from the threat or use of force against the territorial integrity or political independence of any state, or in any other manner inconsistent with the Purposes of the United Nations. ${ }^{83}$

The general rule, which the ICJ has found to constitute customary international law, ${ }^{84}$ can therefore be said to be that the use of force is prohibited by international law. However, there are two exceptions to this general rule included in the text of the UN Charter, namely: (i) UNSC authorisation of the use of force and (ii) self-defence, while there is a third basis pursuant to which the resort to force can be said to fall beyond the scope of Article 2(4) of the UN Charter, i.e., military assistance on request. ${ }^{85}$ As the following paragraphs demonstrate, Egypt appears to rely on all three bases to justify its May 2017 airstrikes against non-State targets in Libya.

\subsection{In Accordance with Resolution 2292}

The UN Charter empowers the UNSC, the UN organ charged with "primary responsibility for the maintenance of international peace and security', ${ }^{86}$ to permit the use of force in certain circumstances, set out in Chapter VII of the same treaty. Article 39 of the UN Charter states that the UNSC 'shall determine the existence of any threat to the peace, breach of the peace, or act of aggression and shall make recommendations, or decide what measures shall be taken in accordance with Articles 41 and 42 , to maintain or restore international peace and security' ${ }^{87}$ Article 42 of the constituent instrument of the UN adds:

Should the Security Council consider that measures provided for in Article 41 would be inadequate or have proved to be inadequate, it may take such action by air, sea, or land forces as may be necessary to maintain or restore international peace and security. Such action may include demonstrations, blockade, and other operations by air, sea, or land forces of Members of the United Nations. $^{88}$

The UNSC can accordingly authorise the use of force if the following two conditions are met: (i) the body has determined that there is a threat to the peace, breach of the peace, or act of aggression; and (ii) the organ judges that measures listed in

\footnotetext{
83 Art. 2(4) UN Charter.

${ }^{84}$ Military and Paramilitary Activities in and against Nicaragua (Nicaragua v. United States of America) (Merits) [1986] ICJ Reports 14 (Nicaragua), pp. 98-100.

85 See Visser (2019), convincingly arguing that intervention by invitation does not constitute a third 'exception' to the prohibition on the use of force.

86 Art. 24(1) UN Charter.

87 Art. 39 UN Charter.

88 Art. 42 UN Charter.
} 
Article 41 of the UN Charter, i.e., measures short of the use of force, ${ }^{89}$ are insufficient to maintain or restore international peace and security.

The day after Egypt's armed forces executed a series of airstrikes on Libyan territory, which might appear to constitute a prima facie violation of the prohibition on the use of force discussed in the preceding section, Egypt's Ambassador and Permanent Representative to the UN, Amr Abdellatif Aboulatta, reported this resort to force in a letter to the President of the UNSC (Letter). ${ }^{90}$ Egypt's report could be reasonably interpreted as invoking the authorisation of the UN organ as a legal justification for its airstrikes. On the other hand, it couldequally reasonably - be argued that Egypt merely wished to underscore that its use of force was compatible with the jus ad bellum more generally insofar as it was justified by self-defence and/or by the consent of Libya. The pertinent part of the Letter reads:

These measures are being taken in accordance with the relevant Security Council resolutions, including resolution 2292 (2016) concerning the situation in Libya, which urges Member States to combat by all means, in accordance with the Charter of the United Nations and international law, threats to international peace and security caused by terrorist acts. ${ }^{91}$

The operative paragraph of Resolution 2292 to which the Letter refers states, in relevant part, as follows:

Urges Member States to combat by all means, in accordance with their obligations under the Charter of the United Nations and other obligations under international law, including international human rights law, international refugee law and international humanitarian law, threats to international peace and security caused by terrorist acts ... ${ }^{92}$

The UNSC employs similar, albeit not identical, language in both earlier and later resolutions addressing the situation in Libya. ${ }^{93}$ Though, at least prima facie, this paragraph might appear to support the argument that the UNSC did, in fact, authorise the Egyptian airstrikes, as Dapo Akande and Marko Milanovic claim, the phrase 'combat by all means' is 'standard language in relation to counter

\footnotetext{
89 Art. 41 UN Charter provides as follows: 'The Security Council may decide what measures not involving the use of armed force are to be employed to give effect to its decisions, and it may call upon the Members of the United Nations to apply such measures. These may include complete or partial interruption of economic relations and of rail, sea, air, postal, telegraphic, radio, and other means of communication, and the severance of diplomatic relations.'

90 Letter dated 27 May 2017 from the Permanent Representative of Egypt to the United Nations addressed to the President of the Security Council, UN Doc. S/2017/456, 1 June 2017 (Letter).

91 Ibid.

92 UNSC Res. 2292, above n. 9, para. 2.

93 See e.g. UNSC Res. 2161, UN Doc. S/RES/2161, 17 June 2014, preamble para. 5; UNSC Res. 2174, UN Doc. S/RES/2174, (27 August 2014, preamble para. 8; UNSC Res. 2213, UN Doc. S/RES/2213, 27 March 2015, preamble para. 5; UNSC Res. 2214, UN Doc. S/RES/2214, 27 March 2015, preamble para. 10, para. 3; UNSC Res. 2238, UN Doc. S/RES/2238, 10 September 2015, preamble para. 10.
} 
terrorism measures not involving the use of force'. ${ }^{94}$ Indeed, the UNSC neither explicitly 'authorises' the use of force by UN Member States in the text of Resolution 2292 - or other related resolutions - nor 'decides' that they ought to take such action. ${ }^{95}$ Thus, though the UNSC is 'Acting under Chapter VII of the Charter of the United Nations" ${ }^{96}$ and reaffirms "its determination that terrorism, in all forms and manifestations, constitutes one of the most serious threats to peace and security' ${ }^{97}$ in the Preamble to Resolution 2292, there is no 'decision' authorising the use of force. The conclusion reached by Akande and Milanovic with respect to Resolution 2249-in which the UN body, inter alia, denounced a series of ISorchestrated terrorist attacks — can therefore be reasonably applied to Resolution 2292:

This difference in language itself suggests that though the Council contemplates, and perhaps would even welcome, the use of force by states, it does not authorize such action. This lack of authorization is made clearer from the fact that the resolution calls for all necessary measures, "in compliance with international law, in particular the United Nations Charter". This wording suggests that measures taken should comply with other rules of international law, including the jus ad bellum rules in the Charter. Thus, the resolution is to be seen as only encouraging states to do what they can already do under other rules of international law. It neither adds to, nor subtracts from, whatever existing authority states already have. ${ }^{98}$

This conclusion also finds support in subsequent State practice. As Christine Gray observes:

Significantly, Resolution 2249 was not later relied on by states as authorizing their use of force in Syria. When the UK and Germany wrote to the Security Council after the resolution was passed, to report that they would now use force against ISIS in Syria, they did refer to Resolution 2249 as confirming that ISIS was a global and unprecedented threat to international peace and security, but they claimed to be acting in self-defence rather than under a Chapter VII authorization. ${ }^{99}$

Turning from whether the UNSC can be viewed as having authorised the use of force to whether Egypt's use of force was conducted in accordance with its 'obligations under the Charter of the United Nations and other obligations under international

\footnotetext{
94 Akande and Milanovic (2015), referring to UNSC Res. 2213, above n. 93; UNSC Res. 2214 above n. 93. For a similar view, see Casey-Maslen (2020), p. 84.

95 Cf. Akande and Milanovic (2015), discussing UNSC Res. 2249, UN Doc. S/RES/2249, 20 November 2015.

96 UNSC Res. 2292, above n. 9, preamble para. 17.

97 Ibid., preamble para. 16. This language echoes Art. 39 UN Charter with respect to 'any threat to the peace'.

98 Akande and Milanovic (2015).

99 Gray (2018), p. 386.
} 
law, ${ }^{100}$ the following paragraphs consider whether the airstrikes were lawful on the grounds of self-defence.

\subsection{In Self-Defence}

The opening paragraph of the Letter appears to suggest that Egypt sees its use of force as having been conducted in accordance with the right, enshrined in Article 51 of the UN Charter and in customary international law, ${ }^{101}$ of States to carry out such measures in individual or collective self-defence. The Letter's first paragraph provides as follows:

I write pursuant to Article 51 of the Charter of the United Nations in order to inform the Security Council that the Egyptian armed forces are carrying out a number of necessary and proportionate air strikes against terrorist organizations in Libya. In so doing, they are exercising their legitimate right to self-defence and acting in coordination with the national army of Libya. This action is being taken in the light of intelligence indicating that the organizations carried out a series of armed terrorist attacks within Egyptian territory, attacks that originated on Libyan territory. Most recently, on 26 May 2017, they targeted innocent Egyptian civilians in the town of Minya, in southern Egypt. That incident constitutes an attack on the sovereignty and territorial integrity of Egypt. ${ }^{102}$

The following paragraphs will examine whether the conditions precedent to resorting to force in self-defence-and the criteria limiting the scope of such actionwere met.

\subsubsection{Armed Attack}

Both Article 51 of the UN Charter and customary international law limit the exercise of States' right to use force in self-defence to cases in which the concerned State has suffered an 'armed attack'. ${ }^{103}$ Accordingly, in order that Egypt might establish the legality of its May 2017 cross-border airstrikes, this condition must be satisfied. ${ }^{104}$ But what qualifies as an armed attack under the jus ad bellum? The text of the UN Charter is silent on this matter. ${ }^{105}$ Guidance can, however, be found in customary international law. This guidance, and the academic literature on this

\footnotetext{
$\overline{100}$ UNSC Res. 2292, above n. 9, para. 2.

101 Nicaragua, above n. 84, para. 94.

102 Letter, above n. 90.

103 Art. 51 UN Charter; Nicaragua, above n. 84, p. 103.

104 Oil Platforms (Islamic Republic of Iran v. United States of America) (Merits) [2003] ICJ Reports 161 (Oil Platforms), p. 189. What is more, Egypt must discharge the burden of proving the existence of an armed attack.

${ }^{105}$ For discussion of the relationship between the use of force, armed attack, and aggression as defined in UNGA Res 3314, UN Doc. A/RES/29/3314, 14 December 1974, see Ruys (2010), pp. 127-139. See also O'Connell et al. (2019), pp. 129-135.
} 
question, centres, at least in part, on two issues: (i) the threshold of force required to constitute an armed attack and (ii) the perpetrator of the armed attack. These issues will now be addressed in turn.

The jurisprudence of the ICJ implies the existence of a threshold that must be reached before it can be demonstrated that the concerned State has been the victim of an armed attack. For instance, in Military and Paramilitary Activities in and against Nicaragua (Nicaragua), the ICJ drew the express distinction between 'the most grave forms of the use of force (those constituting an armed attack) ... [and] other less grave forms'. ${ }^{106}$ In the Court's view, the two categories are distinguishable by their 'scale[s] and effects' 107 and by their 'circumstances ... [and] possible motivations', ${ }^{108}$ the latter of which Gray reasonably describes as 'obscure'. ${ }^{109}$ As for specific examples, the ICJ has held that 'mere frontier incident[s]' would fall short of satisfying the threshold, ${ }^{110}$ but cross-border action by a State's armed forces, ${ }^{111}$ 'the sending by or on behalf of a State of armed bands, groups, irregulars or mercenaries, which carry out acts of armed force against another State of ... [comparable] gravity', ${ }^{112}$ and even 'the mining of a single military vessel' could all qualify as armed attacks. ${ }^{113}$ In addition, the Court's case law appears to leave open the possibility that a series of attacks that fail to reach the threshold might, taken together, constitute an armed attack, ${ }^{114}$ a view endorsed by a number of scholars based on their assessment of relevant State practice and opinio juris. ${ }^{115}$ In light of the low bar set by the jus ad bellum framework in this context, it is therefore difficult to challenge Egypt's assertion that the series of attacks against Coptic Christians on Egyptian territory ${ }^{116}$ for which IS claimed responsibility ${ }^{117}$ satisfied the threshold required to constitute an

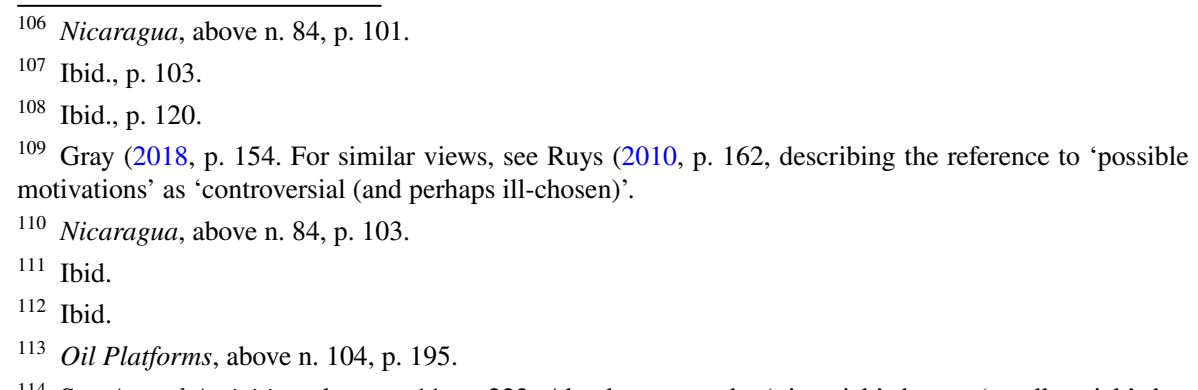

114 See Armed Activities, above n. 11, p. 223. Also known as the 'pin prick' theory, 'needle prick' theory, or 'accumulation of events' theory. See Ruys (2010), p. 168; Gray (2018), p. 164.

115 Ruys (2010), p. 169, citing e.g. Ago (1980), pp. 69-70; Blum (1976), p. 233; Bowett (1972), p. 9; Brownlie (1961) p. 245; Constantinou (2000), p. 64; Dinstein (2005), pp. 230-231; Feder (1987), pp. 395-432; Gazzini (2005), pp. 143-144; Higgins (1963), pp. 201-202; Stahn (2003), p. 46. Cf. International Law Association, Committee on the Use of Force, Final Report on Aggression and the Use of Force, 78 International Law Association Reports of Conferences 588 (ILA Report), p. 596 (2018), observing that 'There is some, not entirely consistent, support for the theory, but it is unclear whether it has been widely accepted.'.

116 For the purposes of the present assessment, the 'series of attacks' to which the article refers at this juncture is limited to those that took place in Egypt. The analysis therefore excludes the attack against Coptic Christians in Sirte, Libya, in response to which Egypt conducted separate military operations. For analysis of the legality of this earlier use of force, see Bannelier-Christakis (2016), pp. 756-758.

117 See above n. 44-49 and accompanying text. Notably, Egypt makes explicit reference to the May 2017 attack in Minya. See Letter, above n. 90. 
armed attack. But the question remains whether Egypt's right to use force in selfdefence can be triggered by an armed attack perpetrated a non-State actor. It is to this issue that the analysis now turns.

Beginning again with the case law of the ICJ, as noted in Sect. 1 of the present article, ${ }^{118}$ the majority of the Court in the Wall Advisory Opinion opined that force used in self-defence by a victim State is only lawful in the event that it has suffered an armed attack conducted by another State, ${ }^{119}$ a position from which it arguably did not depart in Armed Activities. ${ }^{120}$ But the ICJ's view is not universally shared. Indeed, Monica Hakimi identifies multiple positions vis-à-vis the use of defensive force against non-State actors at the time when States launched operations against IS in Syria, each of which has 'some support in the practice and secondary literature[,] [though] ... none was widely accepted as the correct interpretation of the law'. ${ }^{121}$ The first such position-the most restrictive-accords with that expressed by the majority of the ICJ in the Wall Advisory Opinion and Armed Activities, that is to say that an armed attack must either be attributable to another State or that another State must have been substantially involved therein, to trigger the attacked State's right to respond with force in self-defence. ${ }^{122}$ The May 2017 Egyptian airstrikes do not appear to comply with this restrictive interpretation of the jus ad bellum, nor does Egypt attempt to justify its use of force in these terms. On the contrary, the Letter provides as follows:

The Government of the Arab Republic of Egypt stresses that the defensive strikes are directed solely at the members and positions of terrorist organizations, and not at the State of Libya. It is important to bear in mind the prevalent security situation in Libya: in certain areas of the country, conditions have deteriorated and the State has lost control. Terrorist organizations have thus gained an opportunity to attack Egypt from those areas. ${ }^{123}$

Egypt therefore seems to express views similar to those States and international lawyers who espouse the second-less restrictive-position that Hakimi articulates, ${ }^{124}$

\footnotetext{
118 See above n. 10 and accompanying text.

119 Wall Advisory Opinion, above n. 10, p. 194.

120 Armed Activities, above n. 11, pp. 222-223. Having found that 'the legal and factual circumstances for the exercise of a right of self-defence by Uganda against the DRC were not present', the majority continued: 'Accordingly, the Court has no need to respond to the contentions of the Parties as to whether and under what conditions contemporary international law provides for a right of self-defence against large-scale attacks by irregular forces.' Cf. Tams (2009), p. 384, arguing that 'the Court's majority was far more equivocal' in Armed Activities than in the Wall Advisory Opinion.

121 Hakimi (2015), p. 4.

122 Ibid., pp. 4-7, citing e.g. Ruys (2010), pp. 486-489; Antonopoulos (2008), pp. 169-171. As far as scholars who embrace this restrictive position are concerned, see Hakimi (2015), pp. 6-7, citing Randelzhofer and Nolte (2012), p. 1417; Tladi (2013), p. 572; O'Connell (2013), p. 383.

123 Letter, above n. 90.

124 In Hakimi's words: 'three grounds for permitting such force are plausibly available: (1) the territorial State actively harbors or supports the non-State actors, or lacks governance authority in the area from which they operate, (2) the territorial State is unable or unwilling to address the threat that the non-State actors pose, and (3) the threat is located in the territorial State. To be clear, each of these grounds for
} 
namely those of the opinion that 'defensive force against non-State actors is at least sometimes lawful'. ${ }^{125}$

Albeit at a stretch, ${ }^{126}$ this paragraph of Egypt's report could be read as indicating tacit support from Egypt for the 'unwilling or unable' standard, ${ }^{127}$ whereby the victim State of an armed attack by a non-State actor can resort to the permissible use of force in self-defence if the State on whose territory the group operates cannotor will not-take effective action to suppress such violence. ${ }^{128}$ This doctrine finds limited support in State practice, most notably after the 11 September 2001 attacks against the United States of America. ${ }^{129}$ It was following these attacks that what Michael Schmitt terms a 'normative reassessment' of the jus ad bellum schema took place in the international community, ${ }^{130}$ a reassessment that recognised the right to use defensive force also in response to armed attacks perpetrated by non-State actors. ${ }^{131}$ As far as concrete examples of 'explicit' ${ }^{132}$ State support for the unwilling or unable standard are concerned, Russia's 2002 resort to force in Georgia, ${ }^{133}$ Israel's 2006 use of force against non-State targets in Lebanon, ${ }^{134}$ and Turkey's use of force in northern Iraq in 2007 and $2008^{135}$ are frequently cited, while Elena Chachko and Ashley Deeks identify several more 'ambiguous' examples ${ }^{136}$ as well as cases of States' 'implicit endorsement' of the standard. ${ }^{137}$ At the same time, however, there is

\section{Footnote 124 (Continued)}

permitting defensive force has some interpretive space and overlaps with the others. The three are best conceived as concentric circles; as one moves from the first ground to the third, the scope of permissible defensive actions expands.' Hakimi (2015), p. 8.

125 Ibid., p. 7, citing Reinold (2011), p. 285; Tams (2009), p. 360.

${ }^{126}$ At first glance, it might be unclear how Egypt could determine that Libya was unwilling or unable to suppress the militant violence if, at the time it took defensive military action, the identity of the perpetrators of the armed attack was not yet known. In order that this argument might carry any weight, it would have to be assumed that Egypt possessed intelligence that the attack emanated from a non-State actor operating from Libyan territory at the time at which it launched its airstrikes in response thereto.

${ }^{127}$ For analysis of the content of this standard, see Deeks (2012).

${ }^{128}$ Ibid., p. 487.

${ }^{129}$ Cf. Tams (2009), p. 367, discussing States' rejection of a right to use unilateral force against terrorists in the preceding decades.

${ }^{130}$ Schmitt (2007), p. 451. For similar views, see Cassese (2001), p. 996, observing that the 11 September 2001 attacks-and States' responses thereto-'dramatically altered' the jus ad bellum framework; Van Steenberghe (2010).

${ }^{131}$ Cf. Corten (2010), p. 196, expressing the opinion that 'the precedent of $9 / 11$ was certainly a turning point in the fight against terrorism insofar as it prompted States to speed up their cooperation in this domain. It is not established, though, that this turning point has led to a radical change in the rules of the jus contra bellum that might henceforth be invoked outside the context of inter-State relations.'

${ }^{132}$ Chachko and Deeks (2016).

${ }^{133}$ See e.g. ibid.; Deeks (2012), p. 486; Reinold (2011), pp. 252-257.

134 See e.g. Schmitt (2008), p. 163; Lubell (2010), pp. 250-255; Reinold (2011), pp. 263-268; Chachko and Deeks (2016).

135 See e.g. Ruys (2008), p. 355; Deeks (2012), pp. 486-487; Chachko and Deeks (2016); Reinold (2011), pp. 268-272.

136 Chachko and Deeks (2016).

${ }^{137}$ Ibid. 
ample State practice and opinio juris indicating 'a certain reluctance' on the part of the international community to embrace this doctrine. ${ }^{138}$

Not least in view of this ambiguity, the better view is that Egypt relies on the fact that Libya has 'lost control' 139 to justify its resort to the use of force. In other words, Libya 'lacks governance authority' in the areas of its territory from which militants launched operations-including the 26 May 2017 attack-targeting Coptic Christians in Egypt. ${ }^{140}$ The position that armed attacks carried out by non-State actors operating in ungoverned areas of neighbouring States' territory-that is, without any involvement on the part of the 'host' State-can trigger the victim State's right to use defensive force in response enjoys State support. For example, Hakimi lists interventions by Israel in Lebanon, by the United States of America in Pakistan, by Ethiopia in Somalia, and by France in Mali as instances of interventions that drew at least some approval from States, ${ }^{141}$ while Judges Kooijmans and Simma also endorsed the position in similar terms in their respective separate opinions in Armed Activities. ${ }^{142}$

Can it thus be stated at this stage that Egypt was the victim of an armed attack, thereby triggering its right to use force in self-defence? In the opinion of the present author, the series of attacks against Coptic Christians on Egyptian territory for which IS militants subsequently claimed responsibility fulfils the requisite criteria not only in terms of the threshold, but also with respect to the author of the attack. In other words, it is argued that Egypt's 2017 use of force against non-State targets in eastern Libya constitutes another 'hole' - that is, in the form of State practice-in the reasoning of the majority of the ICJ in the Wall Advisory Opinion. ${ }^{143}$ In addition, Egypt's report of its use of force to the UNSC following the airstrikes ${ }^{144}$ could be said to constitute opinio juris supporting a wider understanding of the right to self-defence. ${ }^{145}$ For the avoidance of doubt, the argument put forward here is that the 'hole in the Wall' exists (and is not simply 'emerging'), such that Egypt is able to 'walk through it' in a legal sense. ${ }^{146}$ Although the attacks in question cannot be attributed to Libya, a position that

\footnotetext{
138 Corten (2016a), p. 791. For a similar conclusion, see Brunnée and Toope (2018), p. 277, finding that 'the unwilling or unable standard is currently supported by only five countries: the USA, Israel, Australia and Turkey unequivocally, and the UK ambiguously'.

139 Letter, above n. 90.

140 Hakimi (2015), p. 8.

141 Ibid., pp. 9-12. Kenya's 2011 use of force in self-defence against Al-Shabaab militants operating from ungoverned areas of Somalia - an operation which garnered broad international backing, albeit after Kenya had secured the consent of the de jure Somali government-could also be viewed as supporting this standard. For discussion of this use of force, see Birkett (2013).

142 See Hakimi (2015), p. 10, citing Armed Activities, above n. 11, p. 314 (separate opinion of Judge Kooijmans); Armed Activities, above n. 11, p. 337 (separate opinion of Judge Simma).

143 Wall Advisory Opinion, above n. 10, p. 194.

144 Letter, above n. 90.

145 Cf. Ruys (2008), p. 359, observing, with respect to Turkey's operations against non-State actors in Iraq, that 'the lack of explicit legal justification and the generally muted reactions of third states make it difficult to identify the opinio juris implicit in the Turkish precedent'.

146 Thanks to Luca Ferro for the discussion that led to the inclusion of this clarification (and the terms thereof).
} 
Egypt does not espouse, the jus ad bellum has evolved to permit the use of defensive force against non-State actors in the circumstances discussed in the preceding paragraphs. But this interim conclusion does not necessarily mean that Egypt's use of force in self-defence was permissible under the jus ad bellum. All such uses of force must comply with two further criteria: (i) necessity and (ii) proportionality. The following section will examine the compliance of the 2017 Egyptian airstrikes against non-State targets on Libyan territory with these two requirements.

\subsubsection{Necessity and Proportionality}

As with the definition of armed attack, though the text of Article 51 of the UN Charter is silent as to any limits on using force in self-defence, ${ }^{147}$ constraints are found in customary international law. ${ }^{148}$ The then Secretary of State of the United States of America, Daniel Webster, clearly articulated two such constraints in the aftermath of the 1837 Caroline affair, a case involving the use of force by British troops against a vessel - the Caroline-on the territory of the United States of America. ${ }^{149}$ Webster wrote following this incident that the Government of the United Kingdom had to demonstrate 'a necessity of self-defence, instant, overwhelming, leaving no choice of means, and no moment for deliberation' in order for its use of force against the vessel to have been permissible. ${ }^{150}$ Webster continued: 'It will be for [the British Government] to show, also, that the local authorities ... did nothing unreasonable or excessive; since the act, justified by that necessity of self-defence, must be limited by that necessity and kept clearly within it. ${ }^{151}$ Despite some debate in the literature as to whether the Caroline affair ought to be regarded as a case of self-defence, ${ }^{152}$ the constraints on the exercise of the use of force, that is to say necessity and proportionality, ${ }^{153}$ are widely held to be integral to the jus ad bellum. ${ }^{154}$ This is the case particularly following the adoption of the UN Charter. ${ }^{155}$ Accordingly, in order that

\footnotetext{
147 Nicaragua, above n. 84, p. 94.

148 Ibid.; Legality of the Threat or Use of Nuclear Weapons (Advisory Opinion) [1996] ICJ Reports 226, p. 245; Oil Platforms, above n. 104, p. 183; Armed Activities, above n. 11, p. 223.

149 For a more elaborate account of the facts of this case, see Jennings (1938), pp. 82-84.

150 Exchange of Diplomatic Notes between the United Kingdom and Ireland and the United States of America, Letter from Mr. Webster to Mr. Fox, 24 April 1841 (1841-1842) 29 British and Foreign State Papers 1129, p. 1138.

151 Ibid.

152 See Gray (2018), p. 158, citing Cot et al. (2005), p. 1330; Kearley (1999); Nicaragua, above n. 84, p. 362 (dissenting opinion of Judge Schwebel).

153 Some scholars identify a separate, third criterion, 'immediacy', while others view this as part of the 'necessity' assessment. See Ruys (2010), p. 169, citing, as examples of scholars in the former category, Constantinou (2000), pp. 159-161; Dinstein (2005), p. 242; Gazzini (2005), pp. 143-146.

154 See Gray (2018), p. 158, noting that 'irrespective of the very dubious status of the Caroline incident as a precedent, necessity and proportionality have played a crucial role in state justification of the use of force in self-defence and in international response.'.

155 See Gardam (2004), p. 140, arguing that 'Irrespective of the theoretical basis legitimating the use of force, necessity and proportionality are regarded as being essential components thereof, although their articulation and application will vary depending on the context.'.
} 
Egypt's 2017 use of force against non-State targets in Libya might be viewed as permissible, these two criteria must be satisfied.

Echoing Webster's nineteenth century formulations following the Caroline incident, uses of force can be said to comply with the necessity requirement if there is 'a temporal link between an armed attack and a defensive response', ${ }^{156}$ a viewpoint that finds support not only in State practice, ${ }^{157}$ but also in the jurisprudence of the ICJ. In Nicaragua, the Court found a lapse in time of 'several months' between the armed attack in question and the purportedly defensive response by the United States of America to be relevant in holding that the necessity criterion was not fulfilled. ${ }^{158} \mathrm{~A}$ second aspect of the necessity requirement is that, before resorting to force, States must first pursue peaceful means; in other words, the use of force must be a 'last resort'. ${ }^{159}$ A third component falls at the-albeit blurry-boundary between the necessity and proportionality criteria, namely that 'the action undertaken ... should in principle be directed against the source(s) of the armed attack(s). ${ }^{160}$ The target(s) of the use of defensive force are consequently also relevant to any assessment of the legality of such operations. ${ }^{161}$

What, then, does the proportionality criterion entail? Although necessarily dependent on the circumstances of the case at hand, ${ }^{162}$ it is generally accepted ${ }^{163}$ that the use of force in self-defence need not be equivalent to that employed in the armed attack as far as 'the forms, substance and strength of the action' are concerned. ${ }^{164}$ Put otherwise, it is the objective of the defensive measures against which the proportionality of such action ought to be weighed. As for what might constitute lawful aims of using force in self-defence, following an analysis of relevant State practice, Tom Ruys reaches the conclusion that the evaluation ought to include both retrospective and prospective elements. ${ }^{165}$ The aims of halting or repelling an attack and deterring or preventing future attacks might thus be seen as legitimate, depending on the facts at issue. As for the factors relevant to determining whether the use of force in self-defence is proportionate, Judith Gardam identifies several such indicators, each of which finds its basis in State practice, namely 'the geographical and destructive scope of the response, the duration of the response, the selection of means and methods of warfare and targets and the effect on third States. ${ }^{166}$ Before testing the

\footnotetext{
156 Ibid., p. 152.

157 Ibid., pp. 149-152.

158 Nicaragua, above n. 84, p. 122.

159 Ruys (2010), p. 95.

160 Ibid., p 108.

161 Many would also consider the 'unwilling or unable' test to constitute an aspect of the necessity criterion. See ILA Report, above n. 115, pp. 16-17. For application of this standard to the instant use of force, see above nn. 126-138 and accompanying text.

162 Ruys (2010), p. 111, referring to the 'inherently contextual nature' of the proportionality principle; Gardam (2004), p. 159.

163 Gardam (2004), pp. 160-162; Gray (2018), pp. 159-160; Ruys (2010), p. 112.

164 Ago (1980), p. 69.

165 Ruys (2010), p. 116. See also Corten (2010), p. 485.

166 Gardam (2004), p. 162.
} 
permissibility of Egypt's use of force against these criteria, however, it should be emphasised that States are afforded a degree of flexibility or-as Yoram Dinstein puts it with respect to proportionality, 'elasticity' — when determining whether their uses of force in self-defence adhere to the necessity and proportionality requirements. ${ }^{167}$ This fact will be taken into consideration in the following paragraphs.

Turning to the legality of Egypt's conduct in light of these two parameters, the Letter explicitly asserts that the 'Egyptian armed forces are carrying out a number of necessary and proportionate air strikes against terrorist organizations in Libya' ${ }^{168}$ adding that 'the defensive strikes are directed solely at the members and positions of terrorist organizations'. ${ }^{169}$ Notably in view of the concern expressed in the literature that reports submitted pursuant to Article 51 of the UN Charter can be used as mere 'propaganda', ${ }^{170}$ much of the Egyptian account of events finds corroboration in sources conceivably less susceptible to partiality on the part of the reporting State. ${ }^{171}$ At the same time, however, doubt has been expressed as to whether the purported perpetrator of the Minya attack, namely the IS militant group, was the target of Egypt's use of force in Libya, an issue to which the analysis will return.

Commencing with the temporal link between the armed attack by the non-State group and Egypt's airstrikes in response, in the view of the present author, this element of necessity is arguably satisfied on the facts. That the Egyptian armed forces responded to the ambush in Minya only 'hours' after its occurrence ${ }^{172}$ does not necessarily imply that the use of defensive force was 'premeditated' or 'retaliatory' in character. ${ }^{173}$ As Ruys observes, 'There is no clear-cut distinction between "premeditated" reprisals and "spontaneous" self-defence'. ${ }^{174}$ Yet, to reach the opposite conclusion would not be unreasonable. As Iran contended in its memorial submitted to the ICJ in Oil Platforms:

Whilst States are entitled to prepare for necessary measures in self-defence ... it is clear that where responsive measures are pre-meditated and pre-planned, then-at least where carried out as planned - they cannot be truly protective. This is for the reason that they will rarely be limited to the necessities of the case, for the "case", the actual location, size and nature of the attack is not known. ${ }^{175}$

\footnotetext{
167 Dinstein (2005), p. 231. See also Ruys (2010), p. 124, arguing that 'customary practice and legal doctrine allow a certain flexibility when evaluating necessity and proportionality in specific cases. This is especially true when the attack ... forms part of a cumulative series of armed attacks.'

168 Letter, above n. 90.

169 Ibid.

170 Green (2015), p. 570.

171 See e.g. Walsh and Youssef (2016a).

172 Aboulenein (2017); Walsh and Youssef (2016a).

173 Ruys (2010), p. 100.

174 Ibid.

175 Memorial Submitted by the Islamic Republic of Iran', Oil Platforms (Islamic Republic of Iran $v$. United States of America) (International Court of Justice, General List No. 90, 8 June 1993), para. 4.36. See also Ruys (2010), p. 100.
} 
It is almost certainly for this reason-namely that there is no unequivocal position discernible from State practice on how immediate defensive responses ought to be viewed - that scholars have argued against a strict application of this aspect of necessity. ${ }^{176}$

Turning to the question of whether the use of armed force by Egypt was a 'last resort', an element of the necessity criterion that arguably carries less legal weight than its immediacy counterpart, ${ }^{177}$ the answer is more straightforward. It could be plausibly argued that peaceful, diplomatic means would have been futile in the instant case in view of Libya's lack of control over the territory from which terrorists launched a series of attacks against Coptic Christians in Egypt. ${ }^{178}$ As the President of Egypt, Abdel Fattah El Sisi, remarked in an address delivered in the immediate aftermath of the May 2017 ambush in Minya:

During the past two years, a thousand four-by-four vehicles that wanted to enter Egypt across the border with Libya were destroyed. During the last three months alone, three hundred four-by-four vehicles that were on their way to Egypt from Libya were destroyed. ${ }^{179}$

This revelation serves to underline the lack of governance authority across swathes of Libyan territory and, in turn, the argument that pacific alternatives would have proved fruitless at the time of the Egyptian use of force.

With respect to the target(s) of the airstrikes, however, the waters become far murkier. For example, the Letter reports that Egypt's airstrikes were directed at 'terrorist organizations in Libya', without mentioning IS by name. ${ }^{180}$ In a similar vein, video footage released via the YouTube account of the Egyptian Ministry of Defence on the day of the airstrikes-showing, inter alia, Egyptian military aircraft taking flight—categorises the target of the operations as 'terrorist groups in Libya' ${ }^{181}$ At the same time, it is reported that IS militants have not had a presence in one of the targeted cities, Derna, since their expulsion in $2015^{182}$ and that Egypt's use of force was a pretext for attacking Islamist groups other than those affiliated with IS in support of General Khalifa Haftar and the LNA, with whom Egypt is

\footnotetext{
176 Ruys (2010), pp. 160-161; Dinstein (2005), p. 210; Ducheine (2008), pp. 247-248; Gardam (2004), pp. 150-151; Gazzini (2005), p. 144; Malanczuk (1997), p. 317; Redsell (2007), p. 80; Verhoeven (2002), pp. 65-66.

177 Ruys (2010), p. 98, arguing that 'Practice indicates that the need to exhaust peaceful means only plays a subsidiary role for the assessment of self-defence claims in response to a prior attack, and that unlawfulness will only result when a manifest unwillingness to address diplomatic channels can be demonstrated.' See also Gardam (2004, p. 153, questioning whether this is a legal requirement or merely desirable.

178 Letter, above n. 90 .

179 The full address is available online. ON Live, 'مُألر ةملك هجوي يس (President Abdel Fattah El Sisi's Address to the Nation]' (YouTube, 26 May 2017) 0:03:13-0:03:34. https:// www.youtube.com/watch? $\mathrm{v}=5 \mathrm{w} 5$-Ngfrqio (Address).

${ }^{180}$ Letter, above n. 90.

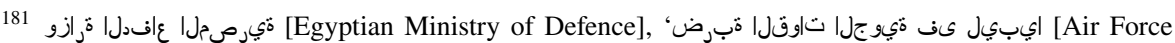
Strike in Libya]' (YouTube, 26 May 2017) 0:00:22-0:00:26 https://www.youtube.com/watch?v=lRoQu j13FPE.

${ }^{182}$ Hennessy-Fiske (2017); Al Jazeera and Agencies (2017).
} 
reportedly allied. ${ }^{183}$ The latter scenario, if accurately depicted, arguably bears similarity to the use of force at issue in Oil Platforms inasmuch as the non-IS-affiliated militant groups might be regarded as a 'target of opportunity' as opposed to an 'appropriate military target'. ${ }^{184}$ Such a conclusion might, as transpired in the foregoing case before the ICJ, undermine the claim that Egypt's use of force complied with the necessity requirement. Notwithstanding this doubt-which might equally apply to IS' claim of responsibility for the armed attack to which Egypt responded with force-and considering the flexibility granted to States when assessing the legality of their uses of defensive force in light of the necessity and proportionality principles, the ensuing paragraphs will examine Egypt's compliance with the remaining facets of these criteria.

Because the Egyptian use of force took place after-as opposed to before or during - the armed attack, it can be reasonably assumed that the objective of the defensive action was to deter or prevent future attacks. Such a conclusion finds support in the foregoing speech by President El Sisi, whose address contained the following remarks:

Any camps that train terrorists to target us in Egypt, will be hit, whether inside or outside Egypt. I hope my message is clear to everyone. We will not hesitate to protect our people from this evil and its people. ${ }^{185}$

Having established the aim of Egypt's action, against which the proportionality of its use of force should be assessed, the case law of the ICJ offers valuable guidance on some of the factors relevant to making such a determination. In Armed Activities, the Court expressed the following obiter opinion with regard to Uganda's use of force in the Democratic Republic of the Congo: 'The Court cannot fail to observe ... that the taking of airports and towns many hundreds of kilometres from Uganda's border would not seem proportionate to the series of transborder attacks it claimed had given rise to the right of self-defence'. ${ }^{186}$ The ICJ was also of the opinion that the disproportionate response by Uganda on this occasion undermined the compliance of its use of force with the necessity requirement. ${ }^{187}$ In contrast, Egypt's response to the IS-orchestrated armed attack was reportedly limited, not only geographically, but also temporally. In geographical terms, the airstrikes were directed at militants in the Libyan city of Derna, ${ }^{188}$ while it was reported that targets in the city of Hun in the Jufra District were also hit. ${ }^{189}$ Taking into account the elasticity granted to States when evaluating whether their uses of defensive force fall within the customary international law constraints on such action, it is difficult to label Egypt's 2017

\footnotetext{
183 See below nn. 200-202 and accompanying text. See also Aboulenein and Elgood (2017).

184 Oil Platforms, above n. 104, p. 198.

185 Address, above n. 179, 0:04:45-0:05:12.

186 Armed Activities, above n. 11, p. 223.

187 Ibid.

188 See e.g. Walsh and Youssef (2016a)

[Airstrikes in Southern Libya after Egyptian

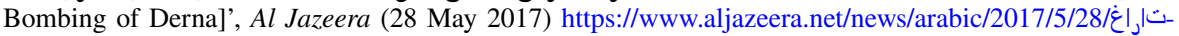
ييرصم-فصوق-دعب-ابيبيل-بيبونج-ثيوج. See also Aboulenein and Elgood (2017).
} 
airstrikes against non-State actors in Libya as disproportionate. This said, questions remain with respect to the targets of the airstrikes and much depends on whether the use of force was directed towards IS militants or other Islamist groups operating from areas of Libyan territory over which the GNA did not exercise control.

It has therefore been demonstrated that Egypt's May 2017 airstrikes arguably satisfied the conditions precedent to the use of force in self-defence. Egypt was the victim of an armed attack — or, it could be contended, a series thereof-perpetrated by a non-State actor operating from an area of Libya over which no authority had control. As for the constraints placed upon the exercise of such force by the principles of necessity and proportionality, an argument can be made that Egypt's airstrikes satisfied this aspect of the jus ad bellum, though to adopt such a position would require a generous interpretation of the abovementioned flexibility afforded to States in applying these two criteria, especially the former. Even though reasonable minds might well argue otherwise, in the view of the present author, Egypt's airstrikes fail to satisfy the customary requirements of necessity and proportionality in relation to self-defence. What remains to be determined, however, is whether Egypt's use of force was rendered permissible by virtue of Libya's consent. It is to this important issue that the present article now turns.

\section{3 'In Coordination with the National Army of Libya'}

Egypt appears to invoke Libya's consent to justify its May 2017 airstrikes. Indeed, in its report to the UNSC, Egypt's Ambassador and Permanent Representative to the UN advises that the Egyptian armed forces are 'acting in coordination with the national army of Libya' in their operations. ${ }^{190}$ Prima facie, this might not raise questions as to the legality of the use of force. As put by Louise Arimatsu and Michael Schmitt, 'To the extent that a State approves foreign operations on its territory, it obviously cannot claim that they amount to either a breach of its sovereignty or the unlawful use of force against it. ${ }^{, 191}$ However, this area of law is not uncontroversial. As Erika de Wet identifies, controversies exist with respect to, inter alia, the authority permitted to issue such invitations or requests and the relationship between consent and the use of force in self-defence in accordance with Article 51 of the UN Charter. ${ }^{192}$ Both of these issues are implicated in the present case.

Effective control and international recognition are habitually assessed when deciding whether an authority ostensibly representing a State is permitted to request military assistance from another State. ${ }^{193}$ Beginning with the former, the regime

\footnotetext{
190 Letter, above n. 90. As to whether can one read 'coordination' as meaning an invocation by Egypt of Libya's 'consent' to the use of force on its territory, though the wording used is (deliberately) vaguewhich might per se indicate an absence of consent - that this question can be answered in the affirmative is borne out in subsequent practice. See below n. 204-205 and accompanying text.

191 Arimatsu and Schmitt (2014), pp. 5-6.

192 De Wet (2020), p. 6.

193 Ibid., p. 22. See also Ruys and Ferro (2016), p. 81, Gerhard Hafner, Rapporteur, 'Present Problems of the Use of Force in International Law Sub-group: Intervention by Invitation' (2009) 73 Annuaire de l'Institut de Droit international 396-402; Corten (2014), p. 453; Doswald-Beck (1985), pp. 199-200.
} 
purporting to be the recognised, de jure government, at a minimum, 'must exercise control of the state machinery; that is, the capital and the state institutions. ${ }^{194}$ At the time of the Egyptian airstrikes, control over Libyan territory, capital, and institutions was divided between the internationally recognised GNA - which exercised nominal control, at most, over the Libyan Army - the HoR, and LNA forces led by General Khalifa Haftar, ${ }^{195}$ as well as other (often-warring) Islamist and tribal factions. Each of these authorities had control over elements of the State machinery, though none could claim effective control, even if construed at its narrowest, in Libya in May 2017.

As for democratic legitimacy, it cannot (yet) be said that this doctrine has supplanted its effective control counterpart as the primary determinant of the authority entitled to extend requests for military assistance on the part of a State. ${ }^{196}$ Moreover, as de Wet observes:

the proliferation of internationally recognized interim governments that came about through negotiated settlements suggests that in conflict situations both effective control and democratic legitimacy of origin at times remain aspirational criteria for governmental recognition. In these situations the recognition of the interim authority as the de jure government is based on the hope that a government in which all major parties to the conflict is represented may ultimately yield the stability required for effective control and the holding of free and fair elections. ${ }^{197}$

The GNA falls into this category. Therefore, though the then-internationally recognised HoR appointed General Haftar to lead Libya's armed forces in March 2015, ${ }^{198}$ after the recognition of the GNA in December 2015, the HoR can no longer be said to represent Libya.

It is therefore pertinent to ask the question: with which 'national army of Libya' was Egypt 'coordinating' in its airstrikes? The original Arabic-language version of Egypt's Letter is identical to its English translation and consequently offers little by way of insight into this issue. ${ }^{199}$ However, contemporaneous reports indicate that it was General Haftar's LNA forces—not the Libyan Army—with whom Egypt was 'coordinating'. ${ }^{200}$ Indeed, the commander of the LNA's Air Force, Saqr AlJaroushi, confirmed as much in a 26 May 2017 interview with Egyptian newspaper,

\footnotetext{
194 Ibid., p. 32, citing Wippman (1996), p. 212; Roth (2010), p. 37; Talmon (2013), p. 233.

195 See Sect. 2.

196 De Wet (2020), p. 73.

197 Ibid.

198 Al-Warfalli (2015).

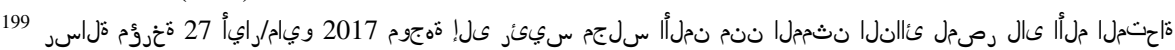
[Letter dated 27 May 2017 from the Permanent Representative of Egypt to the United Nations addressed to the President of the Security Council], UN Doc. S/2017/456, 1 June 2017.

200 See Aboulenein (2017).
} 
El Watan. ${ }^{201}$ In the words of this source, 'The [Egyptian] planes carried out their operations and returned after targeting six terrorist sites, causing a number of deaths and casualties in the ranks of the Shura Council of Mujahideen in Derna.' ${ }^{202}$

Egypt's explicit support for the LNA at the international level adds additional weight to this conclusion. For example, addressing a meeting of the UNSC convened to consider the Report of the Secretary-General on the UN Support Mission in Libya on 19 April 2017, the month preceding the IS-led attack in Minya Governorate, Egypt's Ambassador and Permanent Representative to the UN expressed the following view:

It goes without saying that in order to eliminate the terrorism of the Islamic State in Iraq and the Levant and other groups posing a threat to Libya, a genuine national effort must be carried out, and we believe that the Libyan National Army is in the best position to fulfil such a role. Therefore, the international community must recognize that in order to eliminate the dangers of terrorism and organized crime originating from Libya, the highest degree of support must be provided to the Army as soon as possible. ${ }^{203}$

Such an interpretation would also be consistent with a speech delivered by Egyptian President El Sisi in June 2020:

Any direct intervention by Egypt in Libya now has international legitimacy, either within the framework of the UN Charter (Right to self-defense), or according to the only Libyan elected legitimate authority (Parliament). ${ }^{204}$

The present author shares the opinion expressed by Ferro with respect to this speech, namely that Egypt appears to 'rely on an invitation from [its] favoured governing body in Libya', ${ }^{205}$ a position according with that expressed in the Letter. ${ }^{206}$ As Bannelier-Christakis claimed with respect to Egypt's February 2015 use of force, 'Despite the existence of the civil war in Libya, Egypt considered that the airstrikes were perfectly legal because the invitation emanated from the internationally recognized Libyan government'. ${ }^{207}$ Such a conclusion might have (rightly) held water when the HoR enjoyed international recognition, but it is difficult to reconcile this point of view with the position expressed-unanimously-by the members of the UNSC in December 2015 that the GNA is 'the sole legitimate government of

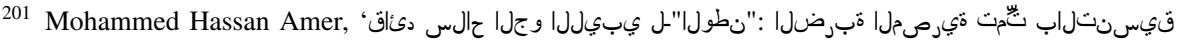
[Commander of the Libyan Air Force to El Watan: The Egyptian Strike was Carried Out in Coordination with Us]', El Watan (26 May 2017) https://www.elwatannews.com/news/details/2134226.

202 Ibid. Cf. Truitte (2018), p. 7, detailing the conflict between the Shura Council of Mujahideen in Derna and Islamic State. On the targets of the airstrikes, see above nn. 180-184 and accompanying text.

${ }^{203}$ UN SCOR, 72nd sess, 7927th mtg, UN Doc. S/PV.7927, 19 April 2017).

204 'Speech by by H.E. President Abdel Fattah El Sisi at the Western Military Zone', State Information Service (23 June 2020) https://www.sis.gov.eg/Story/147756.

${ }^{205}$ Ferro (2020). See also Ferro (2021), developing the Libya-Turkey case study that forms the subject of the foregoing blog post.

${ }^{206}$ Letter, above n. 90. Of course, the Letter includes further legal justifications in the form of selfdefence and, at least arguably, authorisation on the part of the UNSC.

207 Bannelier-Christakis (2016), p. 757.
} 
Libya' ${ }^{208}$ In other words, timing matters. As Gray observes, already in 2016, three regional organisations - the African Union, the League of Arab States, and the European Union-joined the UNSC in recognising the GNA as the 'sole legitimate government of Libya', and, significantly for the purposes of the present analysis, 'stressed that the GNA was the sole legitimate recipient of international security assistance' ${ }^{209}$ De Wet reaches a similar conclusion:

As far as the ... Libyan Government of National Accord is concerned, its continued recognition has been assured through its endorsement in UNSC Resolution 2259 of 23 December 2015 which determined the Government of National Accord to be the sole legitimate government of Libya. Even though this resolution was not adopted under Chapter VII of the UN Carter [sic], it carries significant political weight as it was unanimously adopted. As a result, it is unlikely that any new government will be recognized (prematurely) by states, unless or until the UNSC has withdrawn support for the current Government of National Accord. ${ }^{210}$

Libya's consent is accordingly not as evidently discernible in the instant case as it might have been with respect to earlier uses of force authorised by the HoR. ${ }^{211}$

\section{Conclusion}

Depending on how one interprets Egypt's report of its use of force to the UNSC under Article 51 of the UN Charter, it could be contended that the Egyptian authorities invoke multiple legal grounds justifying the airstrikes in Libya. This article has demonstrated that, without stretching the jus ad bellum to breaking point, none of these justifications - two of which were subsequently repeated in public-render the operations permissible.

As far as UNSC authorisation of the intervention is concerned, it is uncertain whether Egypt purports to rely on Resolution 2292 as a legal basis for its defensive action. Regardless, the foregoing analysis shows that the most convincing interpretation of the UN organ's intent in adopting the measures contained therein was to support - or encourage - those States using force to combat terrorism in Libya justified on other legal grounds, namely in self-defence or with the consent of the recognised, de jure government.

Turning to self-defence, though the present author reached the interim conclusion that Egypt suffered an armed attack - perpetrated not by, nor with the substantial

\footnotetext{
${ }^{208}$ UNSC Res. 2259, above n. 35, para. 3. See also UNSC Res. 2278, above n. 35, preamble para. 3. See also De Wet (2020), p. 62, citing UN SCOR 70th sess, 7598th mtg, UN Doc. S/PV.7598, 23 December 2015. De Wet observes that 'While not adopted under Chapter VII of the UN Charter, the unanimous support within the UNSC for the resolution reflected strong international political backing of the Government of National Accord.'.

${ }^{209}$ Gray (2018), p. 105, citing UNSC Res. 2238, UN Doc. S/RES/2238, 10 September 2015; 'Joint Communique on Libya', 22 September 2016, https://eeas.europa.eu/node/10289_en.

${ }^{210}$ De Wet (2020), p. 69, citing UNSC Res. 2259, above n. 35, para. 3.

${ }^{211}$ Cf. Bannelier-Christakis (2016), pp. 756-758.
} 
involvement of, another State, but by a non-State actor - thereby triggering the right to respond with defensive force, the airstrikes arguably failed to meet the criteria constraining the exercise of such force. The discussion in Sect. 3.2.2 highlighted the uncertainty over the target(s) of the Egyptian airstrikes, which might undermine the claim that the operations were permissible. At the same time, the author acknowledges both that States are afforded some flexibility in assessing their uses of force in light of necessity and proportionality and that IS' declaration that its militants were responsible for the killings in Minya should be regarded with a similar level of caution. Whether the use of force was permissible in self-defence therefore depends on the amount of elasticity one affords to States under the jus ad bellum. The reaction of (affected) third States and international organisations does little to clarify these muddy waters. This said, the GNA's unequivocal condemnation of the intervention hardly bolsters the argument that the airstrikes were lawful, particularly when contrasted with the very limited public support expressed for the operations.

A similar conclusion can be reached with regard to the third and final justification, i.e., that the use of force was lawful in view of Libya's consent thereto. The preceding paragraphs demonstrate that, even if Egypt purported to rely on the invitation or request of the HoR - as opposed to the LNA - to intervene, this body was no longer internationally recognised as the de jure government of Libya in May 2017. Nor did it enjoy effective control. While the GNA could not be said to satisfy the latter criterion either, the widespread international support for this regime-expressed by all members of the UNSC, the African Union, the League of Arab States, and the European Union-is impossible to ignore in this context.

In sum, therefore, the only possible legal basis on which Egypt might rely is the right to use force in self-defence, though, as discussed, this is shaky ground. While this article aims to underscore that the jus ad bellum permits a State to resort to defensive force when it suffers an armed attack perpetrated by a non-State actor acting alone, all such uses of force must still comply with the necessity and proportionality requirements. It would demand a broad reading of the flexibility afforded to States in applying these criteria to find that Egypt's 26 May 2017 use of force against non-State targets in Libya was permissible under the current jus ad bellum schema. Not least in view of the muted reaction of third States and international organisations to the airstrikes, the present author cannot countenance such an interpretation.

Acknowledgements The author wishes to acknowledge the invaluable assistance of Ahmed Abofoul in locating many of the Arabic-language sources quoted and cited in this article and for translating them into English. The author is also grateful to Luca Ferro for his critical review and ensuing discussion of an earlier draft of this article. Finally, the author would like to thank the members of the Editorial Board for their constructive feedback on the manuscript prior to publication.

Open Access This article is licensed under a Creative Commons Attribution 4.0 International License, which permits use, sharing, adaptation, distribution and reproduction in any medium or format, as long as you give appropriate credit to the original author(s) and the source, provide a link to the Creative Commons licence, and indicate if changes were made. The images or other third party material in this article are included in the article's Creative Commons licence, unless indicated otherwise in a credit line to the material. If material is not included in the article's Creative Commons licence and your intended use is not permitted by statutory regulation or exceeds the permitted use, you will need to obtain permission directly from the copyright holder. To view a copy of this licence, visit http://creativecommons.org/licen ses/by/4.0/. 


\section{References}

Aboulenein A (2017) Egypt to press ahead with air strikes after Christians attacked. Reuters (29 May 2017). https://www.reuters.com/article/us-libya-security-idUSKBN18P0GP

Aboulenein A, Elgood G (2017) Is Egypt bombing the right militants in Libya? Reuters (31 May 2017). https://www.reuters.com/article/us-egypt-security-analysis-idUSKBN18R2GE

Ago R (1980) Addendum to the eighth report on state responsibility, by Mr. Roberto Ago. Yearb Int Law Comm II:13-70

Akande D, Milanovic M (2015) The constructive ambiguity of the Security Council's ISIS resolution. EJIL: Talk! https://www.ejiltalk.org/the-constructive-ambiguity-of-the-security-councils-isis-resol ution/. Accessed 16 October 2021

Al-Warfalli A (2015) Libya's Haftar appointed army chief for recognized government. Reuters (2 March 2015). https://www.reuters.com/article/us-libya-security-army/libyas-haftar-appointed-army-chieffor-recognized-government-idUSKBNOLY1AB20150302

Anderson JL (2015) The unravelling. The New Yorker (16 February 2015). https://www.newyorker.com/ magazine/2015/02/23/unravelling

Antonopoulos C (2008) Force by armed groups as armed attack and the broadening of self-defence. Neth Int Law Rev 55:159-180

Aragón Cardiel JL, Davis A, Macherel L (2018) Modern self-defense: The use of force against non-military threats. Columbia Hum Rights Law Rev 49:99-182

Arimatsu L, Schmitt MN (2014) Attacking 'Islamic State' and the Khorasan group: surveying the international law landscape. Columbia J Transnatl Law Bull 53:1-29

Badi E (2020) Russia isn't the only one getting its hands dirty in Libya. Foreign Policy (21 April 2020). https://foreignpolicy.com/2020/04/21/libyan-civil-war-france-uae-khalifa-haftar/

Bannelier K, Christakis T (2013) Under the UN security council's watchful eyes: military intervention by invitation in the Malian conflict. Leiden J Int Law 26:855-874

Bannelier-Christakis K (2016) Military interventions against ISIL in Iraq, Syria and Libya, and the legal basis of consent. Leiden J Int Law 29:743-775

Birkett DJ (2013) The legality of the 2011 Kenyan invasion of Somalia and its implications for the jus ad bellum. J Confl Security Law 18:427-451

Blum YZ (1976) State response to acts of terrorism. Germ Yearb Int Law 19:223-237

Bowett D (1972) Reprisals involving recourse to armed force. Am J Int Law 66:1-36

Bozkurt A (2019) Full text of new Turkey, Libya sweeping security, military cooperation deal revealed. Nordic Monitor (14 December 2019). https://www.nordicmonitor.com/2019/12/full-text-of-new-turkey-libya-sweeping-security-military-cooperation-deal-revealed/

Brownlie I (1961) The use of force in self-defence. Br Yearb Int Law 37:183-268

Brunnée J, Toope SJ (2018) Self-defence against non-state actors: are powerful states willing but unable to change international law? Int Comp Law Q 67:263-286

Casey-Maslen S (2020) Jus ad bellum: the law on inter-state use of force. Hart Publishing, Oxford

Cassese A (2001) Terrorism is also disrupting some crucial legal categories of international law. Eur J Int Law 12:993-1001

Chachko E, Deeks A (2016) Which states support the 'unwilling and unable' test? Lawfare. https://www. lawfareblog.com/which-states-support-unwilling-and-unable-test. Accessed 16 October 2021

Constantinou A (2000) The right of self-defence under customary international law and article 51 of the United Nations Charter. Bruylant, Brussels

Corten O (2010) The law against war: the prohibition on the use of force in contemporary international law. Hart Publishing, Oxford

Corten O (2014) Le droit contre la guerre, 2nd edn. Pedone, Paris

Corten O (2016a) The 'unwilling or unable' test: Has it been, and could it be, accepted? Leiden J Int Law 29:777-799

Corten O (2016b) A plea against the abusive invocation of self-defence as a response to terrorism. EJIL: Talk! https://www.ejiltalk.org/a-plea-against-the-abusive-invocation-of-self-defence-as-a-responseto-terrorism/. Accessed 16 October 2021

Cot J-P, Forteau M, Pellet A (eds) (2005) La Charte des Nations Unies: commentaire article par article, 3rd edn. Economica, Paris

De Wet E (2020) Military assistance on request and the use of force. Oxford University Press, Oxford 
Deeks A (2012) 'Unwilling or unable': towards a normative framework for extraterritorial self-defence. Va J Int Law 52:483-550

Dinstein Y (2005) War, aggression and self-defence, 4th edn. Cambridge University Press, Cambridge

Doswald-Beck L (1985) The legal validity of military intervention by invitation of the government. $\mathrm{Br}$ Yearb Int Law 56:189-252

Ducheine P (2008) Krijgsmacht, geweldgebruik \& terreurbestrijding. Wolf Legal Publishers, Nijmegen Eljarh M (2014) The Supreme Court decision that's ripping Libya apart. Foreign Policy (4 November 2014). https://foreignpolicy.com/2014/11/06/the-supreme-court-decision-thats-ripping-libya-apart

Fahim K, Zway SA (2014) Violence and uncertainty mar Libyan election for a new parliament. The New York Times (25 June 2014). https://www.nytimes.com/2014/06/26/world/africa/violence-and-uncer tainty-mar-libyan-election-for-a-new-parliament.html

Fahim K, Zway SA (2015) Libya's rival factions sign deal for unity government. The New York Times (17 December 2015). https://www.nytimes.com/2015/12/18/world/africa/libya-unity-government. html

Feder NM (1987) Reading the U.N. Charter connotatively: toward a new definition of armed attack. NY Univ J Int Law Politics 19:395-432

Ferro L (2020) A Libyan playground for foreign powers: presenting the case for "negative equality". Opinio Juris. http://opiniojuris.org/2020/06/26/a-libyan-playground-for-foreign-powers-presentingthe-case-for-negative-equality/. Accessed 16 October 2021

Ferro L (2021) The doctrine of 'negative equality' and the silent majority of states. J Use Force Int Law $8: 4-33$

Gardam J (2004) Necessity, proportionality and the use of force by states. Cambridge University Press, Cambridge

Gazzini T (2005) The changing rules on the use of force in international law. Manchester University Press, Manchester

Gray C (2018) International law and the use of force, 4th edn. Oxford University Press, Oxford

Green JA (2015) The article 51 reporting requirement for self-defense actions. Va J Int Law 55:563-624

Hakimi M (2015) Defensive force against non-state actors: the state of play. Int Law Stud 91:1-31

Hennessy-Fiske M (2017). Islamic state claims responsibility for attack on Coptic Christians in Egypt that left 29 dead. Los Angeles Times (27 May 2017). https://www.latimes.com/world/la-fg-isisegypt-20170527-story.html

Henry E (2017) Alleged acquiescence of the international community to revisionist claims of international customary law (with special reference to the jus contra bellum regime). Melb J Int Law 18:260-297

Higgins R (1963) The development of international law through political organs of the United Nations. Oxford University Press, London, New York

International Crisis Group (2015) Libya: getting Geneva right (Middle East and North Africa Report No. 157, 26 February 2015). https://www.crisisgroup.org/middle-east-north-africa/north-africa/libya/ libya-getting-geneva-right

International Crisis Group (2016) The Libyan political agreement: time for a reset (Middle East and North Africa Report No. 170, 4 November 2016). https://www.crisisgroup.org/middle-east-northafrica/north-africa/libya/libyan-political-agreement-time-reset

International Crisis Group (2020) Turkey wades into Libya's troubled waters (Europe Report No. 257, 30 April 2020). https://www.crisisgroup.org/europe-central-asia/western-europemediterranean/turkey/ 257-turkey-wades-libyas-troubled-waters

Jennings RY (1938) The Caroline and McLeod cases. Am J Int Law 32:82-99

Kearley T (1999) Raising the Caroline. Wis Int Law J 17:325-346

Kirkpatrick DD (2012) Braving areas of violence, voters try to reshape Libya. The New York Times (8 July 2012). https://www.nytimes.com/2012/07/08/world/africa/libyans-vote-in-first-election-inmore-than-40-years.html

Kirkpatrick DD, Callimachi R (2015). Islamic state video shows beheadings of Egyptian Christians in Libya. The New York Times (15 February 2015). https://www.nytimes.com/2015/02/16/world/ middleeast/islamic-state-video-beheadings-of-21-egyptian-christians.html

Lubell N (2010) Extraterritorial use of force against non-state actors. Oxford University Press, Oxford

Maghur AK (2014) A legal look into the Libyan Supreme Court ruling. Atlantic Council (8 December 2014). https://www.atlanticcouncil.org/blogs/menasource/a-legal-look-into-the-libyan-supre me-court-ruling/

Malanczuk P (1997) Akehurst's modern introduction to international law, 7th edn. Routledge, London 
O’Connell ME (2013) Dangerous departures. Am J Int Law 107:380-386

O'Connell ME, Tams CJ, Tladi D (2019) Self-defence against non-state actors. Cambridge University Press, Cambridge

QNA (2020) Qatar, Libya sign MoU on security cooperation. The Peninsula (27 October 2020). https:// thepeninsulaqatar.com/article/27/10/2020/Qatar,-Libya-sign-MoU-on-security-cooperation

Randelzhofer A, Nolte G (2012) Article 51. In: Simma B et al (eds) The charter of the United Nations, a commentary, vol II. Oxford University Press, Oxford, pp 1397-1428

Redsell G (2007) Illegitimate, unnecessary and disproportionate: Israel's use of force in Lebanon. Camb Student L Rev 3:70-85

Reinold T (2011) State weakness, irregular warfare, and the right to self-defense post-9/11. Am J Int Law 105:244-286

Roth BR (2010) Secessions, coups and the international rule of law: assessing the decline of the effective control doctrine. Melb J Int Law 11:393-440

Ruys T (2008) Quo vadit jus ad bellum?: a legal analysis of Turkey's military operations against the PKK in northern Iraq. Melb J Int Law 9:334-364

Ruys T (2010) 'Armed attack' and article 51 of the UN Charter: evolutions in customary law and practice. Cambridge University Press, Cambridge

Ruys T, Ferro L (2016) Weathering the storm: legality and legal implications of the Saudi-led military intervention in Yemen. Int Comp Law Q 65:61-98

Ruys T, Corten O, Hofer A (eds) (2018) The use of force in international law: a case-based approach. Oxford University Press, Oxford

Ryan Y (2014) Libya's parliament moves to small port city as dangers in Tripoli increase. The Washington Post (5 October 2014). https://www.washingtonpost.com/world/middle_east/tripoli-is-so-dange rous-that-even-libyas-parliament-has-moved-out/2014/10/03/9952b54e-4053-11e4-b03f-de718 edeb92f_story.html

Samaan M, Walsh D (2017) Egypt declares state of emergency, as attacks undercut promise of security. The New York Times (9 April 2017). https://www.nytimes.com/2017/04/09/world/middleeast/explo sion-egypt-coptic-christian-church.html

Scharf MP (2016) How the war against ISIS changed international law. Case Western Reserve J Int Law 48:15-68

Schmitt MN (2007) 21st century conflict: can the law survive? Melb J Int Law 8:443-476

Schmitt MN (2008) 'Change direction' 2006: Israeli operations in Lebanon and the international law of self-defense. Mich J Int Law 29:127-164

Stahn C (2003) Terrorist acts as 'armed attack': The right to self-defense, article 51(1/2) of the UN Charter, and international terrorism. Fletcher Forum World Affairs 27:35-54

Starski P (2017) Silence within the process of normative change and evolution of the prohibition on the use of force: Normative volatility and legislative responsibility. J Use Force Int Law 4:14-65

Talmon S (2013) Recognition of opposition groups as the legitimate representative of a people. Chin J Int Law 12:219-253

Tams CJ (2009) The use of force against terrorists. Eur J Int Law 20:359-397

Tladi D (2013) The nonconsenting innocent state: the problem with Bethlehem's principle. Am J Int Law 107:570-576

Truitte K (2018) The Derna Mujahideen Shura Council: a revolutionary Islamist coalition in Libya. Perspect Terrorism 12:4-17

Van Steenberghe R (2010) Self-defence in response to attacks by non-state actors in the light of recent state practice: a step forward? Leiden J Int Law 23:183-208

Van Steenberghe R (2016) The law of self-defence and the new argumentative landscape on the expansionists' side. Leiden J Int Law 29:43-65

Vandewalle D (2012) A history of modern Libya, 2nd edn. Cambridge University Press, Cambridge

Verhoeven J (2002) Les « étirements » de la légitime défense. Annu Fran Droit Int 48:49-80

Visser L (2019) May the force be with you: The legal classification of intervention by invitation. Neth Int Law Rev 66:21-45

Walsh D, Ezz M (2018) ISIS says it was behind deadly attack on Christians in Egypt. The New York Times (2 November 2018). https://www.nytimes.com/2018/11/02/world/middleeast/egypt-copticchristians-ambush.html

Walsh D, Youssef N (2016a) Gunmen in Egypt force Coptic Christian pilgrims from buses and kill 28. The New York Times (26 May 2016). https://www.nytimes.com/2017/05/26/world/middleeast/ egypt-coptic-christian-attack.html 
Walsh D, Youssef N (2016b) ISIS claims responsibility for Egypt church bombing and warns of more to come. The New York Times (13 December 2016). https://www.nytimes.com/2016/12/13/world/ middleeast/egypt-isis-bombing-coptic-christians.html

Wintour P (2019) Libya crisis: Egypt's Sisi backs Haftar assault on Tripoli. The Guardian (14 April 2019). https://www.theguardian.com/world/2019/apr/14/libya-crisis-egypt-sisi-backs-haftar-assau 1t-on-tripoli

Wintour P (2020) UN-backed Libyan forces take key airbase from rebel general. The Guardian (18 May 2020). https://www.theguardian.com/world/2020/may/18/forces-allied-to-libyan-governmentretake-key-al-watiya-airbase

Wippman D (1996) Military intervention, regional organizations and host-state consent. Duke J Comp Int Law 7:209-240

Youssef N (2017) Gunmen attack Cairo church, killing at least 9. The New York Times (29 December 2017). https://www.nytimes.com/2017/12/29/world/middleeast/egypt-church-attack.html

Publisher's Note Springer Nature remains neutral with regard to jurisdictional claims in published maps and institutional affiliations. 